Article

\title{
Preparation of $\mathrm{CaCO}_{3}-\mathrm{TiO}_{2}$ Composite Particles and Their Pigment Properties
}

\author{
Sijia Sun, Hao Ding * (1) and Xifeng Hou \\ Beijing Key Laboratory of Materials Utilization of Nonmetallic Minerals and Solid Wastes, National Laboratory \\ of Mineral Materials, School of Materials Science and Technology, China University of Geosciences (Beijing), \\ Xueyuan Road, Haidian District, Beijing 100083, China; ssjcugb@163.com (S.S.); \\ houxifeng3204114@126.com (X.H.) \\ * Correspondence: dinghao@cugb.edu.cn; Tel.: +86-010-8232-2982
}

Received: 8 May 2018; Accepted: 25 June 2018; Published: 3 July 2018

\begin{abstract}
CaCO}_{3}-\mathrm{TiO}_{2}$ composite particles were prepared with calcium carbonate $\left(\mathrm{CaCO}_{3}\right)$ and $\mathrm{TiO}_{2}$ in stirred mill according the wet grinding method. The pigment properties, morphology, and structure of $\mathrm{CaCO}_{3}-\mathrm{TiO}_{2}$ composite particles and the interaction behaviors between $\mathrm{CaCO}_{3}$ and $\mathrm{TiO}_{2}$ particles were explored. In the $\mathrm{CaCO}_{3}-\mathrm{TiO}_{2}$ composite particles, $\mathrm{TiO}_{2}$ is uniformly coated on the surface of $\mathrm{CaCO}_{3}$ and the firm combination between $\mathrm{CaCO}_{3}$ and $\mathrm{TiO}_{2}$ particles is induced by the dehydration reaction of surface hydroxyl groups. $\mathrm{CaCO}_{3}-\mathrm{TiO}_{2}$ composite particles have similar pigment properties to pure $\mathrm{TiO}_{2}$. The hiding power, oil absorption, whiteness and ultraviolet light absorption of composite particles are close to those of pure $\mathrm{TiO}_{2}$. The application performance of $\mathrm{CaCO}_{3}-\mathrm{TiO}_{2}$ composite particles in the paint is consonant with their pigment properties. The contrast ratio of the exterior paint containing $\mathrm{CaCO}_{3}-\mathrm{TiO}_{2}$ composite particles is equivalent to that of the paint containing the same proportion of pure $\mathrm{TiO}_{2}$.
\end{abstract}

Keywords: $\mathrm{CaCO}_{3}-\mathrm{TiO}_{2}$; composite particle; pigment; wet grinding

\section{Introduction}

$\mathrm{CaCO}_{3}$ is an important inorganic mineral material. Especially, the $\mathrm{CaCO}_{3}$ powder material prepared with various non-metallic minerals, such as aragonite, calcite, and some rocks with calcite as the main ingredient component, has many advantages, such as high purity, high whiteness, good compatibility with organic and inorganic matrices, and low cost $[1,2]$. Therefore, $\mathrm{CaCO}_{3}$ has become the most widely used filler in many industrial products such as plastic, paint, and paper due to its obvious cost advantage compared to most non-metallic minerals [3,4]. In order to further increase the utilization value of $\mathrm{CaCO}_{3}$ and achieve the efficient utilization of mineral resources, it is necessary to develop $\mathrm{CaCO}_{3}$-based composite with oxides, such as $\mathrm{TiO}_{2}[5,6]$. Recently, the composite pigment prepared by coating $\mathrm{TiO}_{2}$ particles on the surface of $\mathrm{CaCO}_{3}$ particles, had received wide attention [7]. The composite pigment can not only increase the utilization efficiency of pigment $\mathrm{TiO}_{2}$, but also reduce the consumption of pigment $\mathrm{TiO}_{2}$. The preparation of the composite pigment will enhance the comprehensive utilization of titanium resource [8-10].

$\mathrm{TiO}_{2}$-coated mineral materials are generally prepared by hydrolysis precipitation coating method [11,12]. Zhou [13] prepared the $\mathrm{TiO}_{2}$-coated barite composite pigments through the hydrolysis of $\mathrm{TiOSO}_{4}$ on the barite surface. Ninness [14] and $\mathrm{Lu}$ [15] prepared $\mathrm{TiO}_{2}$-coated kaolin composite pigments and Gao prepared the anatase and rutile $\mathrm{TiO}_{2}$-coated mica composite pigments through the hydrolysis coating of $\mathrm{TiCl}_{4}[16,17]$. However, a strong acid is produced during the hydrolysis process of titanium salts. $\mathrm{CaCO}_{3}$ is instable in acid media due to its poor acid fastness. Consequently, the $\mathrm{CaCO}_{3}$-based composite could not be prepared through the hydrolysis of titanium salts such as $\mathrm{TiOSO}_{4}$. 
Hence, several methods were developed to prepare $\mathrm{CaCO}_{3}-\mathrm{TiO}_{2}$ composites. Tanabe [18] prepared $\mathrm{CaCO}_{3}-\mathrm{TiO}_{2}$ composite particles through carbonation in the $\mathrm{TiO}_{2}$ system. Liu [19] and Sun [20] prepared $\mathrm{CaCO}_{3}-\mathrm{TiO}_{2}$ composite particles by the sol-gel method and hydrophobic agglomeration method, respectively. However, the above mentioned methods are complicated and expensive, and can hardly realize large-scaled industrial production of $\mathrm{CaCO}_{3}-\mathrm{TiO}_{2}$ composite particles.

The mechanochemical method is widely used to prepare composite materials due to its simple process, low cost, and low pollution. Through the ultra-fine grinding of mineral particles, the surface of mineral particles can be activated, thus slightly changing the crystal structure and physicochemical properties of the surface. Consequently, the interfacial reaction between particles is strengthened to induce the combination. Wang [21] and Chen [22] respectively prepared barite/ $\mathrm{TiO}_{2}$ and $\mathrm{TiO}_{2}$-coated wollastonite composite pigments by the mechanochemical method, and both composite pigments exhibited similar pigment properties to $\mathrm{TiO}_{2}$. However, the combination between barite and $\mathrm{TiO}_{2}$ was induced by electrostatic interactions. Therefore, the combination effect was not firm enough and needs to be enhanced. The light adsorption property or the application performance of the composite pigments was not explored. In this study, $\mathrm{CaCO}_{3}-\mathrm{TiO}_{2}$ composite particles were prepared in the water system according to the mechanochemical method. In addition, the pigment properties, light absorption properties, morphology, and structure of the prepared $\mathrm{CaCO}_{3}-\mathrm{TiO}_{2}$ composite particles were studied and the combination feature and mechanism between $\mathrm{TiO}_{2}$ and $\mathrm{CaCO}_{3}$ particles were also investigated. Additionally, the application performances of $\mathrm{CaCO}_{3}-\mathrm{TiO}_{2}$ composite particles in paint were evaluated.

\section{Methods}

\subsection{Raw Materials}

$\mathrm{CaCO}_{3}$ raw material used as the substrate in this study was produced in Huadian Quanxing Mining Co., Ltd. Manufacturer, Huadian, Jilin Province, China. The purity, hiding power, whiteness, and average particle size of the raw material are respectively $100 \%$ (indicated by $\mathrm{X}$-ray diffractometer), $185 \mathrm{~g} / \mathrm{m}^{2}, 97.82 \%, 1.21 \mu \mathrm{m}\left(\mathrm{d}_{50}\right)$, and $4.87 \mu \mathrm{m}\left(\mathrm{d}_{90}\right)$, indicating that the $\mathrm{CaCO}_{3}$ raw material has the poor hiding property and high whiteness. The $\mathrm{TiO}_{2}$ raw material used in the experiment is commercially available rutile $\mathrm{TiO}_{2}$ produced by sulfuric acid method (Billionschem Co., Ltd., Jiaozuo, China). The whiteness, hiding powder, oil absorption and average particle size of $\mathrm{TiO}_{2}$ are respectively $96.9 \%, 14.61 \mathrm{~g} / \mathrm{m}^{2}, 26.06 \mathrm{~g} / 100 \mathrm{~g}, 0.37 \mu \mathrm{m}\left(\mathrm{d}_{50}\right)$ and $0.55 \mu \mathrm{m}\left(\mathrm{d}_{90}\right)$, indicating the excellent pigment properties of $\mathrm{TiO}_{2}$ raw material. Chemically pure linseed oil (Zhengzhou Tianma Art Paints Co., Ltd., Zhengzhou, China) and distilled water were also used (Beijing Jinxin Hengda Technology and Trade Co., Ltd., Beijing, China).

\subsection{Preparation}

\subsubsection{Preparation of the $\mathrm{CaCO}_{3}-\mathrm{TiO}_{2}$ Composite Particles}

$\mathrm{CaCO}_{3}-\mathrm{TiO}_{2}$ composite particles were prepared with $\mathrm{CaCO}_{3}$ and $\mathrm{TiO}_{2}$ in stirred mill by wet grinding. Firstly, the $\mathrm{CaCO}_{3}$ slurry and $\mathrm{TiO}_{2}$ slurry were prepared. $\mathrm{CaCO}_{3}$ and $\mathrm{TiO}_{2}$ were respectively mixed with water and sodium polyacrylate (dispersant) according to a certain proportion and stirred by a high-speed dispersion machine. Secondly, the $\mathrm{CaCO}_{3}$ and $\mathrm{TiO}_{2}$ slurries were mixed together and ground by a GSDM-S3 type ultrafine grinding mill ( $3 \mathrm{~L}$, Beijing gosdel power\&technology Co. Ltd., Beijing, China) with a speed of $1200 \mathrm{r} / \mathrm{min}$ and the weight ratio of ball to powder was 4:1. After stirring at room temperature and $\mathrm{pH}=8$ for $90 \mathrm{~min}$, the composite slurry was obtained. Finally, the $\mathrm{CaCO}_{3}-\mathrm{TiO}_{2}$ composite particles were obtained after the $\mathrm{CaCO}_{3}-\mathrm{TiO}_{2}$ composite slurry was dried at $100{ }^{\circ} \mathrm{C}$ for $12 \mathrm{~h}$ (Electric thermostaticdrying oven, Tianjin Taisite Instrument Co., LTD, Tianjin, China). 


\subsubsection{Preparation of the Construction Paint for Exterior Wall}

The construction paints for exterior wall was prepared respectively with $\mathrm{CaCO}_{3}-\mathrm{TiO}_{2}$ composite particles and $\mathrm{TiO}_{2}$ particles as pigments. The raw materials were added into a high-speed mixer sequentially according to a certain proportion and then stirred to form a stable paint. In the paint, the $\mathrm{TiO}_{2}$ or the $\mathrm{CaCO}_{3}-\mathrm{TiO}_{2}$ composite particles were used as white pigment, they imparts opacity to the coating by bonding with the film-forming materials. The ground calcium carbonate was used as the main filler, playing a role in filling and reducing the cost of coatings. The total content of white pigment and ground calcium carbonate was $35.5 \mathrm{wt} \%$. Besides, the acrylic emulsion was used as a film former, which allows the coating to be firmly adhered to the substrate to form a continuous film. Several additives including wetting agent, water, dispersant, $\mathrm{pH}$ regulator, defoamer, film-forming additive, leveling agent, and thickener were added to adjust the coating performance.

\subsection{Characterization}

\subsubsection{Structure and Property Characterization}

We observed the morphology of $\mathrm{CaCO}_{3}, \mathrm{TiO}_{2}$, and $\mathrm{CaCO}_{3}-\mathrm{TiO}_{2}$ composite particles by scanning electron microscope (SEM, S-3500N, HITACHI, Tokyo, Japan) under an energy dispersive spectroscope at $5.0 \mathrm{kV}$ and transmission electron microscope (TEM, FEI Tecnai G2 F20, Portland, OR, USA) under an acceleration voltage of $300 \mathrm{kV}$. For morphological observation, the powder samples were dispersed in ethanol solvent and sonicated for $10 \mathrm{~min}$, and then the suspensions were directly dropped to the conductive adhesive or copper net for natural drying. The phase analysis were carried out on the X-ray diffractometer (XRD, D8 ADVANCE, BrukerAXS GmbH, Karlsruhe, Germany) with Cu K $\alpha$ radiation $(\lambda=1.5406 \AA)$ generated at $40 \mathrm{kV}$ and $15 \mathrm{~mA}$ and a scanning rate of $8^{\circ} / \mathrm{min}$. The Fourier-transform infrared (FT-IR) spectra were recorded on an infrared spectroscope (Spectrum 100, PerkinElmer Instruments (Shanghai) Co., Ltd., Shanghai, China) in a scanning range of $4000-400 \mathrm{~cm}^{-1}$. The particle size was tested with centrifugal sedimentation (BT-1500, Dandong Bettersize Instrument (Liaoning) Co., Ltd., Liaoning, China). The whiteness was tested with a whiteness meter (SBDY-1, Shanghai Yuet Feng Instrument Co., Ltd., Shanghai, China). The ultraviolet (UV)-vis spectra of the prepared composite materials were obtained in the range of 200 $800 \mathrm{~nm}$ on a TU-1901 double beam spectrophotometer (Beijing Presee General Instrument Co., Ltd. Beijing, China).

\subsubsection{Property Tests of the $\mathrm{CaCO}_{3}-\mathrm{TiO}_{2}$ Composite Particles and the as-Prepared Paint}

The pigment properties of the $\mathrm{CaCO}_{3}-\mathrm{TiO}_{2}$ composite particles were evaluated in terms of oil absorption, hiding power, and relative hiding power and the previous testing methods [23,24] were adopted.

Oil absorption is an important index of pigments. According to the China National Standard GB/T 5211.15-2014 [25], the index refers to the minimum amount of varnish (linseed oil) required for completely wetting $100 \mathrm{~g}$ pigment.

Hiding power is another important index of pigments. It refers to the minimum amount of pigment required for completely covering a black and white checkerboard. The hiding power of a pigment can be tested according to the China National Industrial Standard HG/T 3851-2006 [26] (the Test Method of Pigment Hiding Power).

The relative hiding power $(\mathrm{R}, \%)$ is defined as the ratio of the hiding power of the composite particles to that of pure $\mathrm{TiO}_{2}$ pigment. The $\mathrm{R}$ value can be calculated as:

$$
\mathrm{R}=\left(\mathrm{H}_{\mathrm{T}} / \mathrm{H}_{\mathrm{CT}}\right) \times 100 \%,
$$

where $\mathrm{H}_{\mathrm{T}}\left(\mathrm{g} / \mathrm{m}^{2}\right)$ and $\mathrm{H}_{\mathrm{CT}}\left(\mathrm{g} / \mathrm{m}^{2}\right)$ are respectively the hiding power values of $\mathrm{TiO}_{2}$ and the $\mathrm{CaCO}_{3}-\mathrm{TiO}_{2}$ composite particles. 
The value of $\Delta \mathrm{R}$ calculated by Equation (2) represents the increase in the hiding power of $\mathrm{TiO}_{2}$ caused by the combination with $\mathrm{CaCO}_{3}$ :

$$
\Delta \mathrm{R}=\mathrm{R}-\mathrm{R}_{0}
$$

where $\mathrm{R}_{0}$ is the mass ratio of $\mathrm{TiO}_{2}$ to the composite particles.

According to the China National Standard GB/T 23981-2009 [27], the contrast ratio of the construction paint for exterior wall (C) can be tested according to the following method. A coating film with a certain thickness was firstly coated on the standard black-and-white plate and then the reflectivity values of black $\left(\mathrm{R}_{\mathrm{B}}, \%\right)$ and white regions $\left(\mathrm{R}_{\mathrm{W}}, \%\right)$ were tested with a reflectivity measuring instrument (C84-III, Tianjing Jinke Material Testing machine Co., Ltd., Tianjing, China). Finally, the contrast ratio of coating film can be obtained by Equation (3) [23]:

$$
\mathrm{C}=\mathrm{R}_{\mathrm{B}} / \mathrm{R}_{W}
$$

The total color difference $(\Delta \mathrm{E})$ between the paint containing $\mathrm{CaCO}_{3}-\mathrm{TiO}_{2}$ composite particles and the paint containing $\mathrm{TiO}_{2}$ pigment can be calculated by Equation (4):

$$
\Delta \mathrm{E}=\left[\left(\mathrm{L}_{\mathrm{T}}^{*}-\mathrm{L}_{\mathrm{CT}}\right)^{2}+\left(\mathrm{a}_{\mathrm{T}}^{*}-\mathrm{a}_{\mathrm{CT}}\right)^{2}+\left(\mathrm{b}_{\mathrm{T}}^{*}-\mathrm{b}_{\mathrm{CT}}\right)^{2}\right]^{1 / 2}
$$

where the $\mathrm{L}_{\mathrm{T}}{ }^{*}, \mathrm{a}_{\mathrm{T}}{ }^{*}$, and $\mathrm{b}_{\mathrm{T}}{ }^{*}$ represent the chromaticity values of coating films containing $\mathrm{TiO}_{2}$ particles; $\mathrm{L}_{\mathrm{CT}}{ }^{*}, \mathrm{a}_{\mathrm{CT}}{ }^{*}$, and $\mathrm{b}_{\mathrm{CT}}{ }^{*}$ represent the chromaticity value of coating films containing $\mathrm{CaCO}_{3}-\mathrm{TiO}_{2}$ composite particles. All the chromaticity values were measured with a portable integrating sphere spectrophotometer (X-Rite Sp60, X-Rite (Shanghai) International Trade Co., Ltd., Shanghai, China).

\section{Results and Discussion}

\subsection{Morphology of $\mathrm{CaCO}_{3}-\mathrm{TiO}_{2}$ Composite Particles}

The uniformity and completeness of $\mathrm{TiO}_{2}$ coating on the surfaces of minerals are important influencing factors of the pigment properties of minerals- $\mathrm{TiO}_{2}$ composite particles. Therefore, we investigated the morphology of $\mathrm{CaCO}_{3}$ and $\mathrm{TiO}_{2}$ raw materials, as well as $\mathrm{CaCO}_{3}-\mathrm{TiO}_{2}$ composite particles with different mass ratios of $\mathrm{TiO}_{2}$. Corresponding SEM and TEM images are shown in Figure 1.
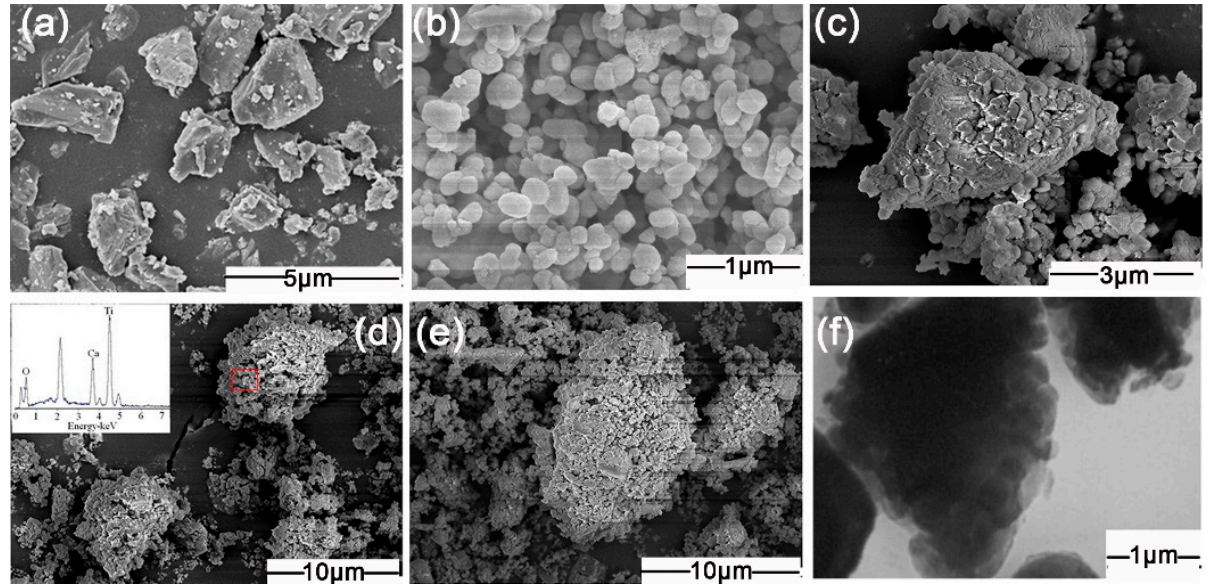

Figure 1. Scanning electron microscopy (SEM) and transmission EM (TEM) images of $\mathrm{CaCO}_{3}, \mathrm{TiO}_{2}$, and $\mathrm{CaCO}_{3}-\mathrm{TiO}_{2}$. (a) $\mathrm{SEM}$ image of $\mathrm{CaCO}_{3} ;$ (b) $\mathrm{SEM}$ of $\mathrm{TiO}_{2} ;$ ( $\left.\mathbf{c}-\mathbf{e}\right) \mathrm{SEM}$ image of $\mathrm{CaCO}_{3}-\mathrm{TiO}_{2}$ with $\mathrm{TiO}_{2}$ mass ratio of $30 \%, 40 \%$, and $50 \%$; (f) TEM of $\mathrm{CaCO}_{3}-\mathrm{TiO}_{2}(50 \%)$. 
In Figure $1 \mathrm{a}$, the bulk $\mathrm{CaCO}_{3}$ particles with the size of $1-3 \mu \mathrm{m}$ were obvious and the surfaces of $\mathrm{CaCO}_{3}$ particles were smooth, without covering. In Figure $1 \mathrm{~b}$, the granular $\mathrm{TiO}_{2}$ particles with the particle size of $0.2-0.3 \mu \mathrm{m}$ showed good dispersivity. However, after $\mathrm{CaCO}_{3}$ and $\mathrm{TiO}_{2}$ particles were ground together (Figure 1c-e), many fine particles were uniformly coated on the surfaces of $\mathrm{CaCO}_{3}$, and the smooth surface of $\mathrm{CaCO}_{3}$ became rough. As indicated by the Energy Dispersive Spectrometer (EDS) results (Figure 1d), the particles coated on the surfaces of $\mathrm{CaCO}_{3}$ should be $\mathrm{TiO}_{2}$. Apparently, the $\mathrm{CaCO}_{3}-\mathrm{TiO}_{2}$ composite particles were characterized by the uniform $\mathrm{TiO}_{2}$ coating on the surface of $\mathrm{CaCO}_{3}$. Consequently, the $\mathrm{CaCO}_{3}-\mathrm{TiO}_{2}$ composite particles should possess the properties of $\mathrm{TiO}_{2}$, such as the similar pigment properties to that of $\mathrm{TiO}_{2}$.

The uniformity and completeness of the $\mathrm{TiO}_{2}$ coating on the surfaces of $\mathrm{CaCO}_{3}$ particles increased accordingly when the mass ratio of $\mathrm{TiO}_{2}$ increased from $30 \%$ to $50 \%$ (Figure 1c-e). Particularly, when the mass ratio of $\mathrm{TiO}_{2}$ increased to $50 \%$, the surfaces of the $\mathrm{CaCO}_{3}$ particles were almost completely covered by $\mathrm{TiO}_{2}$ particles. Additionally, as shown in the TEM image (Figure 1f), the $\mathrm{CaCO}_{3}-\mathrm{TiO}_{2}$ composite particles are composed of the particles characterized by uniform and dense $\mathrm{TiO}_{2}$ coating on the surface of $\mathrm{CaCO}_{3}$.

\subsection{Binding Properties of $\mathrm{CaCO}_{3}$ and $\mathrm{TiO}_{2}$ Particles}

\subsubsection{XRD Analysis}

Figure 2 shows the $\mathrm{XRD}$ pattern of $\mathrm{CaCO}_{3}, \mathrm{TiO}_{2}$, and $\mathrm{CaCO}_{3}-\mathrm{TiO}_{2}$ composite particles with the $\mathrm{TiO}_{2}$ mass ratio of $50 \%$. There were only calcite and rutile diffraction peaks in the XRD pattern of $\mathrm{CaCO}_{3}-\mathrm{TiO}_{2}$ composite particles, indicating that the composite particles were still composed of caclite and rutile $\mathrm{TiO}_{2}$, and no new phase was produced in the preparation process of the composite particles. Meanwhile, the complete crystal phases of the $\mathrm{CaCO}_{3}$ and $\mathrm{TiO}_{2}$ materials remained without any changes. Therefore, it can be inferred that the binding of $\mathrm{CaCO}_{3}$ and $\mathrm{TiO}_{2}$ particles should occur at the interfacial region of the particles, whether the binding is of a chemical or physical nature.

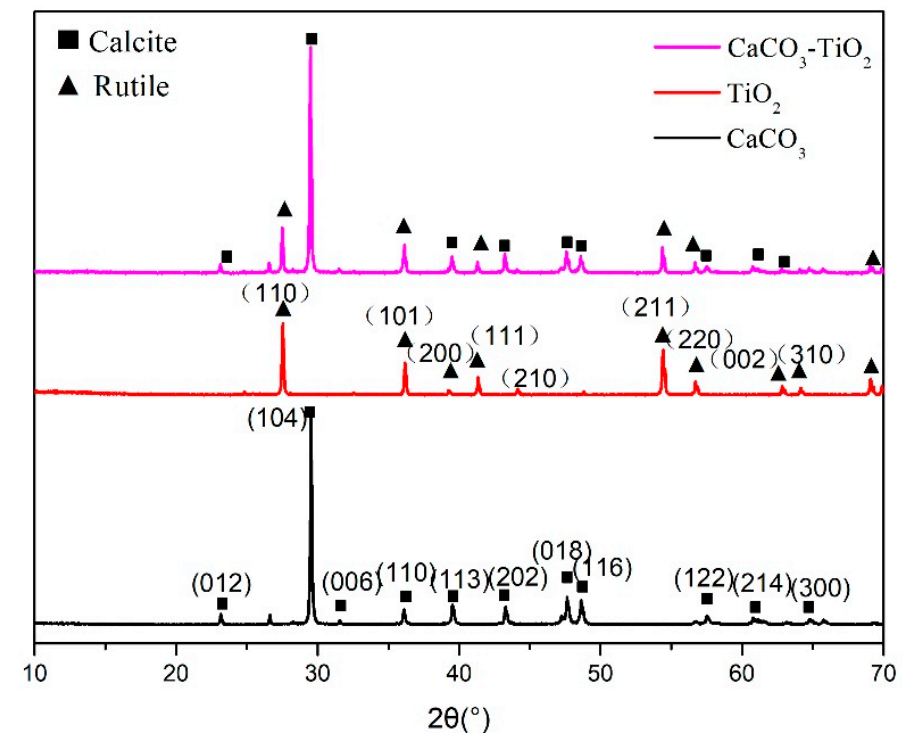

Figure 2. X-ray diffractometer (XRD) patterns of $\mathrm{CaCO}_{3}, \mathrm{TiO}_{2}$, and $\mathrm{CaCO}_{3}-\mathrm{TiO}_{2}$ composite particles.

\subsubsection{Infrared Spectral Analysis}

In addition to the coating behaviors of $\mathrm{TiO}_{2}$, including completeness and orderliness, on the surfaces of mineral particles, the binding properties and binding strength between mineral particles and $\mathrm{TiO}_{2}$ particles are also important influencing factors of the properties of the $\mathrm{TiO}_{2}$-coated composite particle pigments. In order to investigate the binding properties between $\mathrm{TiO}_{2}$ and $\mathrm{CaCO}_{3}$ particles, 
the infra-red (IR) spectra of $\mathrm{TiO}_{2}, \mathrm{CaCO}_{3}$, and $\mathrm{CaCO}_{3}-\mathrm{TiO}_{2}$ composite particles were tested and analyzed (Figure 3). Figure 3a displays several peaks in the range of $400 \sim 700 \mathrm{~cm}^{-1}$, which are ascribed to the stretching vibrations of Ti-O-Ti bonds. These peaks were characteristic peaks of $\mathrm{TiO}_{2}[28,29]$. In Figure $3 \mathrm{~b}$, the absorption peaks at $880 \mathrm{~cm}^{-1}$ and $718 \mathrm{~cm}^{-1}$ were ascribed to the characteristic absorption peaks of $\mathrm{CO}_{3}{ }^{2-}$ in $\mathrm{CaCO}_{3}[30,31]$. Meanwhile, the peak at $3420 \mathrm{~cm}^{-1}$ was ascribed to the hydroxyl groups formed by the reaction between $\mathrm{H}_{2} \mathrm{O}$ and the ions on $\mathrm{CaCO}_{3}$ surface such as $\mathrm{Ca}^{2+}$ and $\mathrm{CO}_{3}{ }^{2-}$. Several changes were observed in the IR spectrum of $\mathrm{CaCO}_{3}-\mathrm{TiO}_{2}$ composite particles (Figure 3c), compared to that of the raw materials. Firstly, the absorption peak of $\mathrm{CO}_{3}{ }^{2-}$ in $\mathrm{CaCO}_{3}$ appeared at $1465 \mathrm{~cm}^{-1}$, showing a shift and broadening phenomenon compared with the absorption peak at $1440 \mathrm{~cm}^{-1}$ in the infrared spectrum of $\mathrm{CaCO}_{3}$. The shifted absorption peak indicated that the chemical environment of $\mathrm{CO}_{3}{ }^{2-}$ changed due to the reaction with other materials, and the broadened absorption peak showed that the association degree between $\mathrm{CaCO}_{3}$ particles increased. Secondly, compared to the characteristic peak of hydroxyl groups at $3420 \mathrm{~cm}^{-1}$ in $\mathrm{CaCO}_{3}$ raw materials (Figure 3b), the characteristic peak of water and hydroxyl groups at $2892 \sim 3300 \mathrm{~cm}^{-1}$ in Figure 3c [32] was broadened and shifted in the direction of the low wave number. Thirdly, there is a clear absorption peak at $1030 \mathrm{~cm}^{-1}$ in Figure 3c, indicating that there might be a chemical bonding behavior related to the formation of Ti-O-Ca bond. According to the above analysis, it can be inferred that the combination of $\mathrm{CaCO}_{3}$ and $\mathrm{TiO}_{2}$ should be realized by the chemical interaction between hydroxyl groups on particle surfaces, so this combination should be firm. Undoubtedly, based on the uniform coating of $\mathrm{TiO}_{2}$ on the surface of $\mathrm{CaCO}_{3}$, the strong combination strength between $\mathrm{CaCO}_{3}$ and $\mathrm{TiO}_{2}$ largely determines the good pigment properties of $\mathrm{CaCO}_{3}-\mathrm{TiO}_{2}$ composite particles.

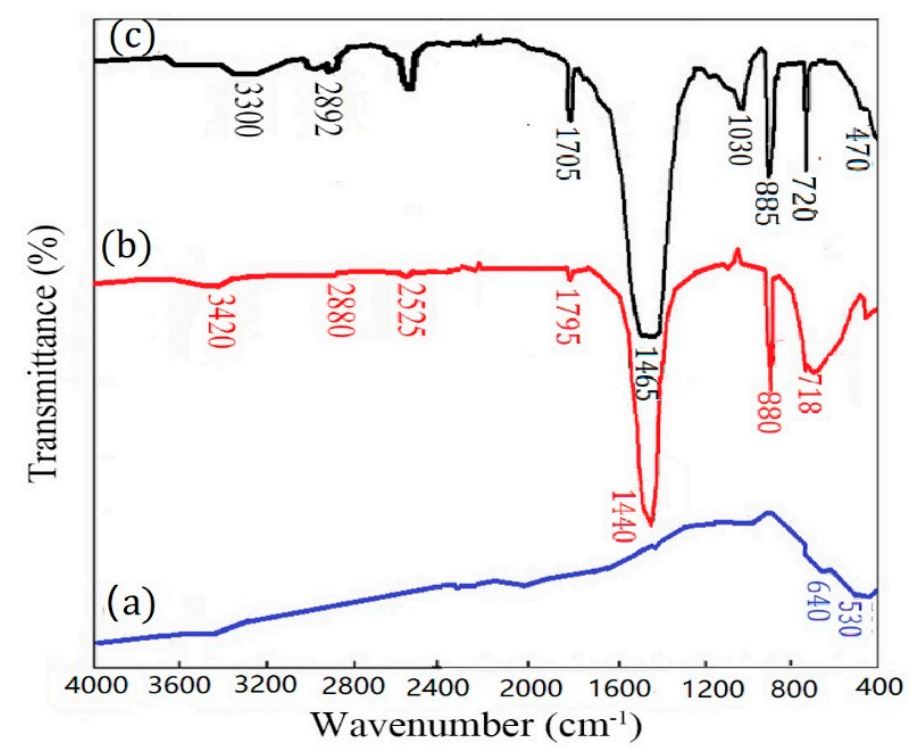

Figure 3. Fourier-transform infrared spectra (FT-IR) spectra of (a) $\mathrm{CaCO}_{3},(\mathbf{b}) \mathrm{TiO}_{2}$, and (c) $\mathrm{CaCO}_{3}-\mathrm{TiO}_{2}$ composite particles.

\subsubsection{Mechanism Analysis}

The hydration behavior of unsaturated ions on the cleavage planes of $\mathrm{CaCO}_{3}$ and $\mathrm{TiO}_{2}$ can explain the formation of surface hydroxyl groups. The calcite $\mathrm{CaCO}_{3}$, which belongs to the tripartite crystal system, is completely cleaved on the plane (1011), and the unsaturated $\mathrm{Ca}^{2+}$ and $\mathrm{CO}_{3}{ }^{2-}$ ions are exposed. The unsaturated $\mathrm{Ca}^{2+}$ on $\mathrm{CaCO}_{3}$ surface will undergo the following hydration reactions:

$$
\begin{gathered}
\mathrm{Ca}^{2+}+\mathrm{H}_{2} \mathrm{O} \rightarrow \mathrm{Ca}(\mathrm{OH})^{+}+\mathrm{H}^{+} \\
\mathrm{Ca}(\mathrm{OH})^{+}+\mathrm{H}_{2} \mathrm{O} \rightarrow \mathrm{Ca}(\mathrm{OH})_{2}+\mathrm{H}^{+}
\end{gathered}
$$


The above hydration reactions of $\mathrm{Ca}^{2+}$ are related to the $\mathrm{pH}$ value. The larger the $\mathrm{pH}$ value is, the stronger the hydration effect is $[33,34]$. Therefore, the hydration reaction of $\mathrm{CaCO}_{3}$ is intense. Obviously, there should be a certain amount of hydroxyl groups on the surfaces of $\mathrm{CaCO}_{3}$ generated in the hydration reactions of $\mathrm{Ca}^{2+}$ and $\mathrm{CO}_{3}{ }^{2-}$. As for $\mathrm{TiO}_{2}$, the hydration reactions of $\mathrm{Ti}^{4+}$ are intense. Hydrolysis reactions and corresponding constants [35] are provided as follows:

$$
\begin{gathered}
\mathrm{Ti}^{4+}+\mathrm{H}_{2} \mathrm{O} \leftrightarrows \mathrm{Ti}(\mathrm{OH})^{3+}+\mathrm{H}^{+}, \mathrm{pk}_{1}=14.15 \\
\mathrm{Ti}(\mathrm{OH})^{3+}+\mathrm{H}_{2} \mathrm{O} \leftrightarrows \mathrm{Ti}(\mathrm{OH})_{2}{ }^{2+}+\mathrm{H}^{+}, \mathrm{pk}_{2}=13.73 \\
\mathrm{Ti}(\mathrm{OH})_{2}{ }^{2+}+\mathrm{H}_{2} \mathrm{O} \leftrightarrows \mathrm{Ti}(\mathrm{OH})_{3}{ }^{+}+\mathrm{H}^{+}, \mathrm{pk}_{3}=13.39 \\
\mathrm{Ti}(\mathrm{OH})_{3}{ }^{+}+\mathrm{H}_{2} \mathrm{O} \leftrightarrows \mathrm{Ti}(\mathrm{OH})_{4}+\mathrm{H}^{+}, \mathrm{pk}_{4}=13.06
\end{gathered}
$$

Therefore, a large amount of hydroxyl groups are formed on the $\mathrm{TiO}_{2}$ surface due to the intense hydrolysis of $\mathrm{Ti}^{4+}$. Consequently, it can be inferred that $\mathrm{CaCO}_{3}$ and $\mathrm{TiO}_{2}$ are combined together by the reaction of hydroxyl groups on their surfaces.

Based on the above analysis, the preparation mechanism of $\mathrm{CaCO}_{3}-\mathrm{TiO}_{2}$ composite particles by the mechanochemical method can be summarized as follows (Figure 4). First, through the high speed stirring of raw materials, the $\mathrm{CaCO}_{3}$ and $\mathrm{TiO}_{2}$ particles can be further dispersed, and then the hydration, dehydration, and other reactions between particles in aqueous media can be promoted because the slight distortion of the lattice of mineral particles and the activation of the particle surface during the grinding process enhances the binding between the surfaces [36]. Second, the high energy imported in the co-grinding process can increase the chance of the collision between $\mathrm{CaCO}_{3}$ and $\mathrm{TiO}_{2}$ particles, overcome the energy barrier of the repulsive interaction between the two particles, and reduce the distance between particles below the range allowing the interaction between functional groups on particle surface. Finally, the firm combination of $\mathrm{CaCO}_{3}$ and $\mathrm{TiO}_{2}$ particles can be achieved by the dehydration reaction among the hydroxyl groups on particle surface.

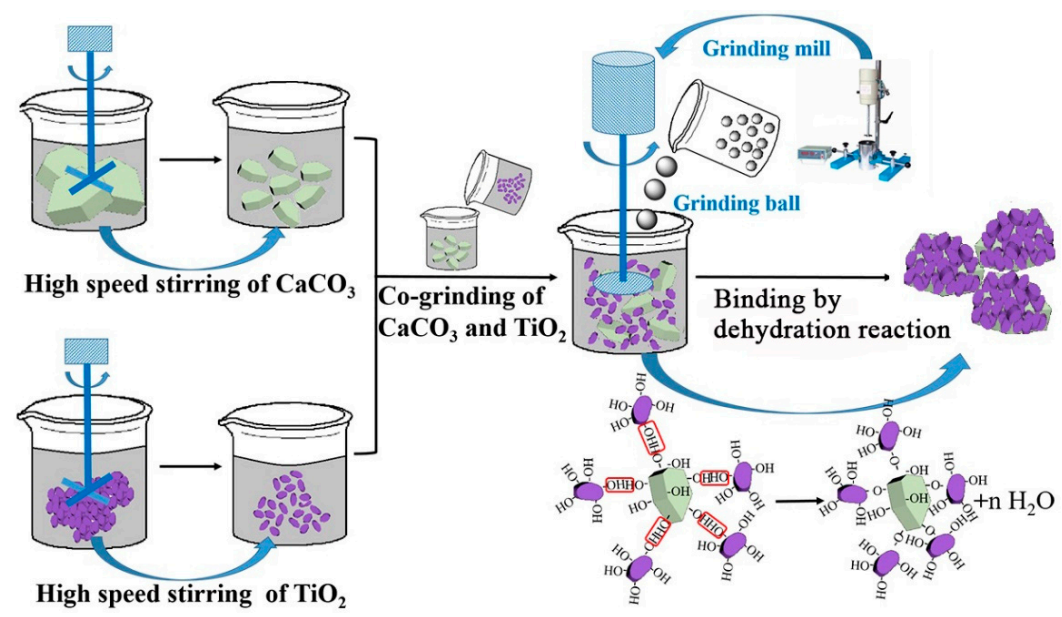

Figure 4. Preparation mechanism of $\mathrm{CaCO}_{3}-\mathrm{TiO}_{2}$ composite particles.

\subsection{Properties of $\mathrm{CaCO}_{3}-\mathrm{TiO}_{2}$ Composite Particles}

\subsubsection{Pigment Properties}

Figure 5 shows the pigment properties of $\mathrm{CaCO}_{3}, \mathrm{TiO}_{2}$ raw materials, and the $\mathrm{CaCO}_{3}-\mathrm{TiO}_{2}$ composite materials with different $\mathrm{TiO}_{2}$ mass ratios, including hiding power, relative hiding power $(\mathrm{R})$, the increased ratio of hiding power $(\Delta \mathrm{R})$, oil absorption, and whiteness.

As shown in Figure $5 \mathrm{a}, \mathrm{CaCO}_{3}-\mathrm{TiO}_{2}$ composite particles exhibited much better hiding properties than $\mathrm{CaCO}_{3}$. When the mass ratio of $\mathrm{TiO}_{2}$ in the $\mathrm{CaCO}_{3}-\mathrm{TiO}_{2}$ composite was only $30 \%$, its hiding 
power reached about $23 \mathrm{~g} / \mathrm{m}^{2}$, which shows much stronger hiding properties than the $\mathrm{CaCO}_{3}$ raw material $\left(185 \mathrm{~g} / \mathrm{m}^{2}\right)$. When the mass ratio of $\mathrm{TiO}_{2}$ increases to $50 \%$, the hiding power and relative hiding power of $\mathrm{CaCO}_{3}-\mathrm{TiO}_{2}$ composite are $17.59 \mathrm{~g} / \mathrm{m}^{2}$ and $82.80 \%(\mathrm{R})$, which was $32.80 \%(\Delta \mathrm{R})$ higher than that of $\mathrm{TiO}_{2}\left(\mathrm{R}_{0}\right)$. As expected, the hiding power and relative hiding power of the $\mathrm{CaCO}_{3}-\mathrm{TiO}_{2}$ composite respectively reached $15.79 \mathrm{~g} / \mathrm{m}^{2}$ and $92.27 \%$ when the $\mathrm{TiO}_{2}$ mass ratio increased to $70 \%$, indicating that the $\mathrm{CaCO}_{3}-\mathrm{TiO}_{2}$ composite have obtained the excellent pigment properties equivalent to that of $\mathrm{TiO}_{2}$ pigment. Obviously, the coating of $\mathrm{TiO}_{2}$ on the surface $\mathrm{CaCO}_{3}$ weakened the properties of $\mathrm{CaCO}_{3}$ and induced the composite particles to exhibit the properties of $\mathrm{TiO}_{2}$. The abovementioned results indicated that the $\mathrm{TiO}_{2}$ particles in the $\mathrm{CaCO}_{3}-\mathrm{TiO}_{2}$ composite exhibited the higher utilization efficiency compared to the pure rutile $\mathrm{TiO}_{2}$ pigment because the coating structure improved the dispersion of titanium dioxide and the synergistic effect of calcium carbonate as a carrier. Meanwhile, the whiteness of $\mathrm{CaCO}_{3}-\mathrm{TiO}_{2}$ composite particles was also close to that of $\mathrm{CaCO}_{3}$ and $\mathrm{TiO}_{2}$, and the oil absorption of $\mathrm{CaCO}_{3}-\mathrm{TiO}_{2}$ composite was similar or less than that of $\mathrm{TiO}_{2}$.
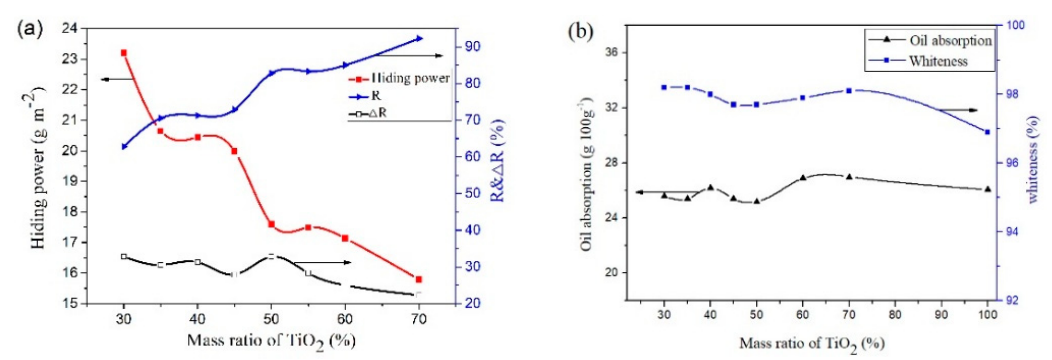

Figure 5. Pigment properties of $\mathrm{CaCO}_{3}-\mathrm{TiO}_{2}$ composite particles with different mass ratios of $\mathrm{TiO}_{2}$. (a) Hiding power $(\mathrm{R})$ and relative hiding power $(\Delta \mathrm{R}),(\mathbf{b})$ Oil absorption and whiteness.

\subsubsection{Optical Property of $\mathrm{CaCO}_{3}-\mathrm{TiO}_{2}$ Composite Particles}

The UV-vis absorption spectra of $\mathrm{CaCO}_{3}-\mathrm{TiO}_{2}$ composite particles, $\mathrm{CaCO}_{3}$ and $\mathrm{TiO}_{2}$ raw materials are shown in Figure 6. All samples almost showed no absorption of visible light in the wavelength range of $400-800 \mathrm{~nm}$, reflecting their characteristics as white inorganic material. However, the three samples are different in the absorption of ultraviolet light in the wavelength range of $200-400 \mathrm{~nm} . \mathrm{CaCO}_{3}$ raw materials exhibited almost no light absorption, but $\mathrm{TiO}_{2}$ and $\mathrm{CaCO}_{3}-\mathrm{TiO}_{2}$ composite particles exhibited strong light absorption. $\mathrm{CaCO}_{3}-\mathrm{TiO}_{2}$ composite particles exhibited less light absorption in the wavelength range of 200-350 nm than $\mathrm{TiO}_{2}$. Unlike $\mathrm{CaCO}_{3}$, the $\mathrm{CaCO}_{3}-\mathrm{TiO}_{2}$ composite particles obtained the same light absorption property as that of $\mathrm{TiO}_{2}$ and the result was in agreement with the previous report [5]. The abovementioned results not only indicated that the $\mathrm{CaCO}_{3}-\mathrm{TiO}_{2}$ composite particles obtained excellent $\mathrm{UV}$ resistance stability, but also reflected the mechanism that $\mathrm{TiO}_{2}$ particles coated on the surface of $\mathrm{CaCO}_{3}$ particles endowed the composite particles with the similar properties of $\mathrm{TiO}_{2}$.

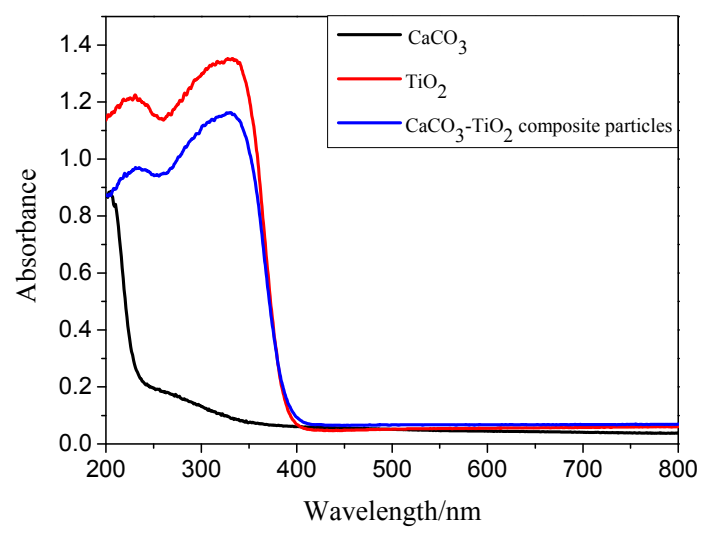

Figure 6. UV-vis absorption spectra of $\mathrm{CaCO}_{3}, \mathrm{TiO}_{2}$, and $\mathrm{CaCO}_{3}-\mathrm{TiO}_{2}$ composite particles. 


\subsubsection{Properties of the Exterior Paint Containing $\mathrm{CaCO}_{3}-\mathrm{TiO}_{2}$ Composite Particles}

Figure 7 shows the property of the exterior paint containing $\mathrm{CaCO}_{3}-\mathrm{TiO}_{2}$ composite particles ( $\mathrm{R}-801$, the mass ratio of $\mathrm{TiO}_{2}$ is $70 \%$ ) and rutile $\mathrm{TiO}_{2}$ (BLR-699). As shown in Figure $7 \mathrm{a}$, when the addition proportions of R-801 and BLR-699 in the paint were only 5\%, the contrast ratios of the obtained paints respectively reached 0.94 and 0.95 , and the two values were close. Moreover, the abovementioned contrast ratios of the paint were higher than the contrast ratio (0.93) of superior products required in China National Standard of Exterior Paints (GB/T 9756-2009) [37]), indicating that R-801 and BLR-699 exhibited excellent pigment properties when they were applied in the paint. When the addition proportions of R-801 and BLR-699 in the paint increased to $10 \%$ or more, the contrast ratio of the paint was increased slightly. The contrast ratio of the paint containing R-801 was always equivalent to that of the paint containing BLR-699, indicating that the application of $\mathrm{CaCO}_{3}-\mathrm{TiO}_{2}$ composite particles as the pigment in the paint for exterior wall could achieve the equivalent covering effect to the paint containing the same proportion of $\mathrm{TiO}_{2}$. When the addition proportion of pigments in the paint is $5 \%$ or $10 \%$, the whiteness of the paint containing R-801 was always lower than that of the paint containing the same proportion of BLR-699 (Figure $7 \mathrm{~b}$ ). However, when the addition proportion of pigments increased to $15 \%$ and $20 \%$, the whiteness of the paint containing R-801 was close to that of the paint containing BLR-699 and the color difference value $(\Delta \mathrm{E})$ was reduced to about 0.7 . As the addition proportion of pigment in the paint for exterior wall is generally high, the comprehensive performance of the paint containing R-801 is equivalent to that of the paint containing BLR-699. As shown in the SEM images of the dry paints respectively containing R-801 and BLR-699 (Figure 8), the two samples all present a continuous form composed of solid particles, such as the polymer formed after emulsion evaporation, binder, pigments, and fillers, indicating that both the R-801and BLR-699 have good compatibility with emulsion.
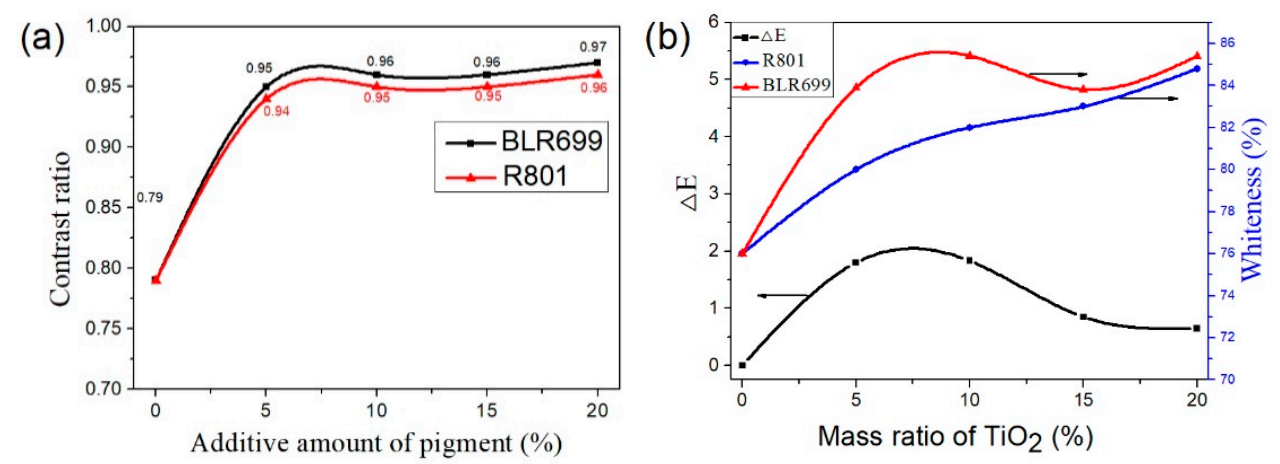

Figure 7. Properties of the two exterior paints respectively containing R-801 and BLR-699. (a) Contrast ratio of paint; (b) Whiteness and chromatic aberration of paint.
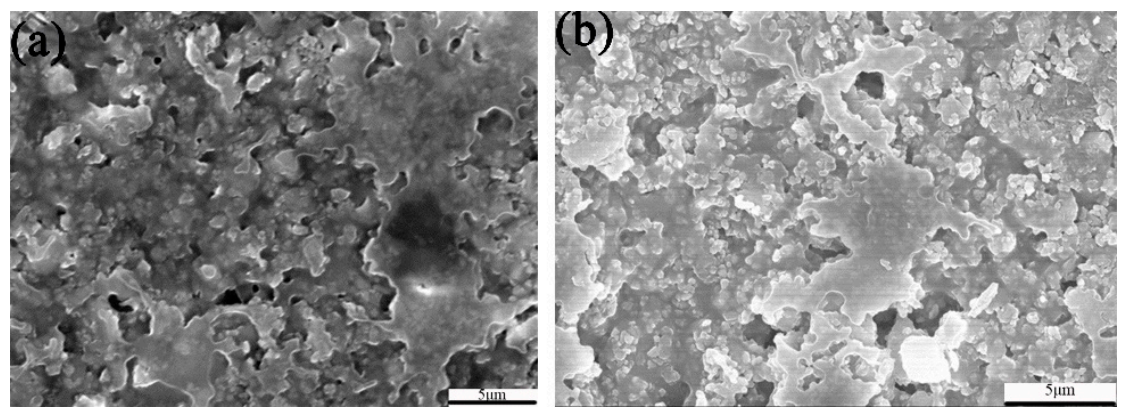

Figure 8. SEM images of two exterior paints respectively containing R-801 (a) and BLR-699 (b). 


\section{Conclusions}

$\mathrm{CaCO}_{3}-\mathrm{TiO}_{2}$ composite particles were prepared with $\mathrm{CaCO}_{3}$ and $\mathrm{TiO}_{2}$ in stirred mill according to the wet grinding method. The composite particles are characterized by the uniform $\mathrm{TiO}_{2}$ coating on the surface of $\mathrm{CaCO}_{3}$. The $\mathrm{CaCO}_{3}$ and $\mathrm{TiO}_{2}$ particles were firmly combined together through the dehydration reaction of hydroxyl groups on their surfaces.

$\mathrm{CaCO}_{3}-\mathrm{TiO}_{2}$ composite particles exhibited similar pigment properties and light absorption property to $\mathrm{TiO}_{2}$. Moreover, the $\mathrm{CaCO}_{3}-\mathrm{TiO}_{2}$ composite particles also showed excellent application performance. The contrast ratio of the exterior construction paint containing $\mathrm{CaCO}_{3}-\mathrm{TiO}_{2}$ composite particles as the pigment was similar to that of paint containing the same proportion of $\mathrm{TiO}_{2}$, and was higher than the contrast ratio (0.93) of superior products required in the China National Standard of Exterior Paints (GB/T 9756-2009 [36]).

Author Contributions: Conceptualization, H.D. and S.S.; Methodology, H.D. and S.S.; Software, S.S.; Validation, H.D., S.S. and X.H.; Investigation, S.S., X.H.; Resources, H.D.; Data Curation, S.S., X.H.; Writing-Original Draft Preparation, H.D. and S.S.; Writing-Review \& Editing, H.D. and S.S.; Supervision, H.D.; Project Administration, H.D.; Funding Acquisition, H.D.

Acknowledgments: This work was supported by the National Natural Science Foundation of China (Grant No. 51474194).

Conflicts of Interest: The authors have declared that there are no competing interests existing in this research.

\section{References}

1. Zheng, S. Processing and Application of Non-Metallic Ore; Chemical Industry Press: Beijing, China, 2003.

2. Fekete, E.; Pukánszky, B.; Tóth, A.; Bertoti, I. Surface modification and characterization of particulate mineral fillers. J. Colloid Interface Sci. 1990, 135, 200-208. [CrossRef]

3. Juntuek, P.; Ruksakulpiwat, C.; Chumsamrong, P.; Ruksakulpiwat, Y. Comparison between mechanical and thermal properties of polylactic acid and natural rubber blend using calcium carbonate and vetiver grass fiber as fillers. Adv. Mater. Res. 2012, 410, 59-62. [CrossRef]

4. Kim, J.J.; Ahn, J.W.; Lee, M.W.; Seo, Y.B. Improving recycled fibres in printing paper by application of an in-situ $\mathrm{CaCO}_{3}$ formation method. Appita J. 2013, 66, 54-58.

5. Tao, H.; He, Y.; Zhao, X. Preparation and Characterization of calcium carbonate-titanium dioxide core-shell $\left(\mathrm{CaCO}_{3} @ \mathrm{TiO}_{2}\right)$ nanoparticles and application in the papermaking industry. Powder Technol. 2015, 283, 308-314. [CrossRef]

6. Lee, S.; Kim, J.Y.; Youn, S.H.; Park, M.; Hong, K.S.; Jung, H.S.; Lee, J.K.; Shin, H. Preparation of a nanoporous $\mathrm{CaCO}_{3}$-coated $\mathrm{TiO}_{2}$ electrode and its application to a dye-sensitized solar cell. Langmuir 2007, 23, 11907-11910. [CrossRef] [PubMed]

7. Ding, H.; Lin, H.; Deng, Y. Minerals-Titanium Dioxide Micro-Nanometer Scale Particle Composition and Functionalization; Tsinghua University Press: Beijing, China, 2016.

8. Pei, R. The Production of $\mathrm{TiO}_{2}$ by Sulfuric Acid Process; Chemical Industry Press: Beijing, China, 1982.

9. Middlemas, S.; Fang, Z.Z.; Fan, P. A new method for production of titanium dioxide pigment. Hydrometallurgy 2013, 131, 107-113. [CrossRef]

10. Yan, Q.; Lei, Y.; Yuan, J. Preparation of titanium dioxide compound pigments based on kaolin substrates. J. Coat. Technol. Res. 2010, 7, 229-237. [CrossRef]

11. Zhao, X.; Li, J.; Zhang, Y. Preparation of nanosized anatase $\mathrm{TiO}_{2}$-coated illite composite pigments by $\mathrm{Ti}\left(\mathrm{SO}_{4}\right)_{2}$ hydrolysis. Powder Technol. 2015, 271, 262-269. [CrossRef]

12. Zhao, X. Preparation and mechanism of $\mathrm{TiO}_{2}$-coated illite composite pigments. Dyes Pigments 2014, 108, 84-92. [CrossRef]

13. Zhou, H.; Wang, M.; Ding, H.; Du, G. Preparation and characterization of barite $/ \mathrm{TiO}_{2}$ composite particles. Adv. Mater. Sci. Eng. 2015, 2015, 878594. [CrossRef]

14. Ninness, B.J.; Bousfirld, D.W.; Tripp, C.P. Formation of a thin $\mathrm{TiO}_{2}$ layer on the surfaces of silica and kaolin pigments through atomic layer deposition. Colloids Surf. A 2003, 214, 195-204. [CrossRef] 
15. Lu, Z.; Ren, M.; Yin, H.; Wang, A.; Ge, C.; Zhang, Y.; Yu, L.; Jiang, T. Preparation of nanosized anatase $\mathrm{TiO}_{2}$-coated kaolin composites and their pigmentary properties. Powder Technol. 2009, 196, 122-125. [CrossRef]

16. Gao, Q.; Wu, X.; Fan, Y.; Zhou, X. Low temperature synthesis and characterization of rutile $\mathrm{TiO}_{2}$-coated mica-titania pigments. Dyes Pigments 2012, 95, 534-539. [CrossRef]

17. Ao, Q.; Wu, X.; Fan, Y. The effect of iron ions on the anatase-rutile phase transformation of titania $\left(\mathrm{TiO}_{2}\right)$ in mica-titania pigments. Dyes Pigments 2012, 95, 96-101.

18. Tanabe, K.; Anabe, K.; Minitsuhashi, K.; Yoshida, T. Titanium Dioxide-Calcium Carbonate Composite Particles. EP US6991677B2, 31 January 2006.

19. Liu, G.; Hu, A.; Zeng, H. Preparation of nano $\mathrm{CaCO}_{3} / \mathrm{TiO}_{2}$ composite particles. Mater. Rev. 2004, 18, 80-82.

20. Sun, S.; Ding, H.; Hou, X. Study on preparation of $\mathrm{TiO}_{2}$-coated $\mathrm{CaCO}_{3}$ composite pigments by hydrophobic agglomeration method. Non-Met. Mines 2017, 40, 26-29.

21. Wang, B.; Ding, H.; Wang, Y. Preparation of barite $/ \mathrm{TiO}_{2}$ composite particle and interaction mechanism between $\mathrm{TiO}_{2}$ and barite particles. Rare Met. Mater. Eng. 2011, 40, 193-197.

22. Chen, W.; Liang, Y.; Hou, X.; Zhang, J.; Ding, H.; Sun, S.; Cao, H. Mechanical grinding preparation and characterization of $\mathrm{TiO}_{2}$-coated wollastonite composite pigments. Materials 2018, 11, 593. [CrossRef] [PubMed]

23. Sun, S.; Ding, H.; Zhou, H. Preparation of $\mathrm{TiO}_{2}$-coated barite composite pigments by the hydrophobic aggregation method and their structure and properties. Sci. Rep. 2017, 7, 10083. [CrossRef] [PubMed]

24. Li, Z.; Huang, C.; Guo, L.; Cui, L.; Zhou, B. Mass production and application of $\mathrm{TiO}_{2} @ \mathrm{CaCO}_{3}$ composites in interior emulsion coatings. Colloids Surf. A 2016, 498, 98-105. [CrossRef]

25. GB/T 5211.15-2014, General Methods of Test for Pigments and Extenders; Standards Press of China: Beijing, China, 2014.

26. HG/T 3851-2006, Covering Power Determination of Dyestuff; National Development and Reform Commission: Beijing, China, 2006.

27. GB/T 23981-2009, Determination of Contrast Ratio of White and Light Coloured Paints; Standards Press of China: Beijing, China, 2009.

28. Bezrodna, T.; Gavrilko, T.; Puchkovska, G.; Shimanovska, V.; Baran, J.; Marchewka, M. Spectroscopic study of $\mathrm{TiO}_{2}$ (rutile)-benzophenone heterogeneous systems. J. Mol. Struct. 2002, 614, 315-324. [CrossRef]

29. Wei, H.; McMaster, W.A.; Tan, J.Z.Y.; Cao, L.; Chen, D.; Caruso, R.A. Mesoporous $\mathrm{TiO}_{2} / \mathrm{g}_{-} \mathrm{C}_{3} \mathrm{~N}_{4}$ Microspheres with enhanced visible-light photocatalytic activity. J. Phys. Chem. C 2017, 121, 22114-22122. [CrossRef]

30. Trezza, M.A.; Lavat, A.E. Analysis of the system $3 \mathrm{CaO} \cdot \mathrm{Al}_{2} \mathrm{O}_{3}-\mathrm{CaSO}_{4} \cdot 2 \mathrm{H}_{2} \mathrm{O}-\mathrm{CaCO}_{3}-\mathrm{H}_{2} \mathrm{O}$ by FT-IR spectroscopy. Cem. Concr. Res. 2001, 31, 869-872. [CrossRef]

31. Chen, J.; Xiang, L. Controllable synthesis of calcium carbonate polymorphs at different temperatures. Powder Technol. 2009, 189, 64-69. [CrossRef]

32. Bezrodna, T.; Puchkovska, G.; Shymanovska, V.; Baran, J.; Ratajczak, H. IR-analysis of H-bonded $\mathrm{H}_{2} \mathrm{O}$ on the pure $\mathrm{TiO}_{2}$ surface. J. Mol. Struct. 2004, 700, 175-181. [CrossRef]

33. Wang, D.; Hu, Y. Solution Chemistry of Flotation; Hunan Science \& Technology Press: Changsha, China, 1988.

34. Iv, T.D.P.; Cygan, R.T.; Mitchell, R. Molecular models of a hydrated calcite mineral surface. Geochim. Cosmochim. Acta 2007, 71, 5876-5887.

35. Perrin, D.D. Stability Constants of Metal-Ion-Complexes; Pergamon Press: Oxford, UK, 1979.

36. Inam, M.A.; Ouattara, S.; Frances, C. Effects of concentration of dispersions on particle sizing during production of fine particles in wet grinding process. Powder Technol. 2011, 208, 329-336. [CrossRef]

37. GB/T 9756-2009, Synthetic Resin Emulsion Coatings for Interior Wall; Standards Press of China: Beijing, China, 2009.

(C) 2018 by the authors. Licensee MDPI, Basel, Switzerland. This article is an open access article distributed under the terms and conditions of the Creative Commons Attribution (CC BY) license (http:/ / creativecommons.org/licenses/by/4.0/). 